\title{
PERAN PUSAT PELAYANAN TERPADU PEMBERDAYAAN PEREMPUAN DAN ANAK (P2TP2A) DALAM MENGATASI KEKERASAN DALAM RUMAH TANGGA
}

\author{
Oleh: \\ Emy Rosnawati \\ Fakultas Hukum Universitas Muhammadiyah Sidoarjo \\ E-mail: emy_lawyer@rocketmail.com
}

\begin{abstract}
Violence against women and children is a violation of human rights. The integrated services centre of the women and children empowerment (Pusat Pelayanan Terpadu Pemberdayaan Perempuan dan Anak/P2TP2A) is an integrated activity founded Ministry of women empowerment and child protection and provide services for the Indonesian people, mainly women and children victims of violence acts. The purpose of this research is to know the service of process in P2TP2A given to women victims of domestic violence and P2TP2A efforts in tackling domestic violence. The research method used the juridical sociological. data collection is done by observation, interview and documentation as well as literature-related literature. Researchers took samples from Sidoarjo P2TP2A because P2TP2A is a pilot project of P2TP2A in other districts. Then analyzed in descriptive qualitative. From the above research it can be concluded that the role of the integrated services centre the empowerment of women and children (P2TP2A) in addressing domestic violence is very effective and in accordance with the mandated in the Act No. 23 years 2004 on the Elimination of Domestic Violence.
\end{abstract}

Keywords: Domestic Violence, Integrated Services Centre, Empowerment of Women and Children

\begin{abstract}
Abstrak
Kekerasan terhadap perempuan dan anak merupakan pelanggaran hak asasi manusia. Pusat Pelayanan Terpadu Pemberdayaan Perempuan dan Anak merupakan kegiatan terpadu yang didirikan Kementerian Pemberdayaan Perempuan dan Perlindungan Anak dan menyediakan pelayanan bagi masyarakat Indonesia terutama Perempuan dan Anak korban tindak kekerasan. Tujuan penelitian ini adalah mengetahui proses pelayanan di diberikan P2TP2A kepada perempuan korban kekerasan dalam rumah tangga dan upaya P2TP2A dalam mengatasi kekerasan dalam rumah tangga. Metode penelitian yang digunakan yuridis sosiologis. Pengumpulan data dilakukan dengan observasi, wawancara dan dokumentasi serta literatur-literatur terkait. Peneliti mengambil sampel dari P2TP2A Sidoarjo karena P2TP2A Sidoarjo merupakan pilot project dari P2TP2A di kabupaten lain. Kemudian dianalisis secara deskriptif kualitatif. Dari penelitian tersebut di atas dapat disimpulkan bahwa peran Pusat Pelayanan Terpadu Pemberdayaan Perempuan dan Anak (P2TP2A) dalam mengatasi kekerasan dalam rumah tangga sangat efektif dan sesuai dengan yang diamanatkan dalam
\end{abstract}


Undang-undang Nomor 23 Tahun 2004 tentang Penghapusan Kekerasan dalam Rumah Tangga.

Kata kunci: Kekerasan dalam Rumah Tangga, Pusat Pelayanan Terpadu Pemberdayaan Perempuan dan Anak

\section{A. PENDAHULUAN}

Kekerasan dalam rumah tangga merupakan salah satu bentuk pelanggaran hak asasi manusia. Korban kekerasan dalam rumah tangga bisa anak, istri, suami, bapak, ibu maupun pembantu rumah tangga. Akan tetapi pengertian kekerasan dalam rumah tangga secara umum diartikan sebagai kekerasan yang dilakukan oleh suami terhadap istri. Penyebab kekerasan dalam rumah tangga diantaranya adalah kesetaraan gender belum berjalan secara optimal serta budaya patriarki dimana laki-laki dipandang lebih dominan dibanding perempuan sehingga perempuan rentan menjadi korban kekerasan. Untuk itu pemerintah mengeluarkan Undang-undang Nomor 23 Tahun 2004 tentang Penghapusan Kekerasan dalam Rumah Tangga (PKDRT).

Pelaksanaan UU PKDRT untuk menangani kekerasan terhadap perempuan dan anak direalisasikan pada tanggal 22 Oktober 2009 pemerintah membentuk Kementerian Pemberdayaan Perempuan dan Perlindungan Anak (PP dan PA). Kemudian Kementerian PP dan PA membentuk Pusat Perlindungan Terpadu Pemberdayaan dan Perlindungan Anak (P2TP2A) berdasarkan Peraturan Menteri Negara Pemberdayaan Perempuan dan Perlindungan Anak Nomor 5 Tahun 2010 tentang Panduan Pembentukan dan Pengembangan Pusat Pelayanan Terpadu. Peraturan tersebut mengatur bahwa masing-masing daerah kabupaten/kota mempunyai kewajiban membentuk lembaga P2TP2A.

P2TP2A mempunyai visi mengedepankan pemberdayaan perempuan dan anak dari tindak kekerasan, sesuai prinsip hak asasi manusia. Sedangkan misi dibentuknya Pusat Pelayanan Terpadu Pemberdayaan Perempuan dan Anak adalah membangun gerakan bersama untuk menghapus kekerasan dan traficking terhadap perempuan dan anak, memberikan pelayanan yang meliputi pendampingan psikologis, advokasi serta informasi terhadap perempuan dan anak yang mengalami tindak kekerasan, menjadikan P2TP2A sebagai basis 
pemberdayaan perempuan dan anak secara preventif, kuratif dan rehabilitatif. ${ }^{1}$ Berdasakarn uraian tersebut maka akan dianalisis proses perlindungan kekerasan terhadap perempuan dan anak serta upaya P2TP2A dalam mengatasi kekerasan dalam rumah tangga.

\section{B. METODE PENELITIAN}

Metode penelitian yang digunakan yuridis sosiologis. Pengumpulan data dilakukan dengan observasi, wawancara dan dokumentasi serta literatur-literatur terkait. Peneliti mengambil sampel dari P2TP2A Sidoarjo karena P2TP2A Sidoarjo merupakan pilot project dari P2TP2A di kabupaten lain. Kemudian dianalisis secara deskriptif kualitatif.

\section{PEMBAHASAN}

1. Kekerasan dalam Rumah Tangga

Kekerasan dalam rumah tangga atau domestic violence adalah rangkaian kata yang terdiri dari dua kata yaitu kekerasan atau violence yang menjadi penekanan utamanya, dan kata rumah tangga atau domestic yang menjelaskan tempat peristiwa violence itu sendiri. Secara sederhana domestic violence dapat diterjemahkan sebagai kekerasan yang terjadi dalam lingkup rumah tangga. $^{2}$ Dalam Pasal 1 ayat (1) UU PKDRT, pengertian kekerasan dalam rumah tangga adalah setiap perbuatan terhadap seseorang terutama perempuan, yang berakibat timbulnya kesengsaraan atau penderitaan secara fisik, seksual, psikologis, dan/atau penelantaran rumah tangga termasuk ancaman untuk melakukan perbuatan, pemaksaan, atau perampasan kemerdekaan secara melawan hukum dalam lingkup rumah tangga. ${ }^{3}$ Sedangkan yang termasuk lingkup rumah tangga adalah: ${ }^{4}$

a. suami istri atau mantan suami istri;

b. orang tua dan anak-anak;

c. orang-orang yang mempunyai hubungan darah;

Visi dan misi Pusat Pelayanan Terpadu Pemberdayaan Perempuan dan Anak. Purnianti dan Kalibonso, Menyingkap Tirai Kekerasan Dalam Rumah Tangga, hIm. 27.

Pasal 1 ayat (1) Undang-undang Nomor 23 Tahun 2004 tentang Penghapusan Kekerasan Dalam Rumah Tangga.

4 Achie Sudiarti Luhulima, 2000, Pemahaman Bentuk-bentuk Tindak Kekerasan Terhadap Perempuan dan Alternatif Pemecahannya, PT. Alumni, Bandung, hlm. 109. 
d. orang yang bekerja membantu kehidupan rumah tangga orang-orang lain yang menetap di sebuah rumah tangga;

e. orang yang hidup bersama dengan korban atau mereka yang masih atau pernah tingal bersama (yang dimaksud dengan orang yang hidup bersama adalah pasangan hidup bersama atau beberapa orang tinggal bersama dalam satu rumah untuk jangka waktu tertentu).

2. Bentuk-bentuk Kekerasan dalam Rumah Tangga

Pada dasarnya bentuk kekerasan dalam rumah tangga adalah merupakan bentuk kekerasan yang tidak berbeda dengan bentuk kekerasan lainnya tetapi di dalamnya terdapat hubungan yang saling menyakiti, dan adanya tujuan pelaku untuk melestarikan kekuasaan dan kendali atas pasangannya. $^{5}$

Mengacu pada Pasal 5 Undang-undang Nomor 23 Tahun 2004 tentang Penghapusan Kekerasan dalam Rumah Tangga, maka kekerasan dalam rumah tangga dapat berwujud: ${ }^{6}$

a. kekerasan fisik, yaitu perbuatan yang mengakibatkan rasa sakit, jatuh sakit atau luka berat;

b. kekerasan psikis, yaitu perbuatan yang mengakibatkan ketakutan, hilangnya rasa percaya diri, hilangnya kemampuan untuk bertindak, rasa tidak berdaya, dan/atau penderitaan psikis berat pada seseorang;

c. kekerasan seksual yang meliputi: pemaksaan hubungan seksual yang dilakukan terhadap orang yang menetap dalam lingkup rumah tangga, pemaksaan hubungan seksual terhadap salah seorang dalam lingkup rumah tangganya dengan orang lain untuk tujuan komersial dan/atau tujuan tertentu;

d. penelantaran dalam rumah tangga, yaitu setiap orang yang menelantarkan orang dalam lingkup rumah tangganya, padahal menurut hukum yang berlaku baginya atau karena persetujuan atau perjanjian ia wajib memberikan kehidupan, perawatan, atau pemeliharaan kepada orang tersebut. Termasuk dalam pengertian penelantaran adalah setiap orang yang mengakibatkan ketergantungan ekonomi dengan cara membatasi 
dan/atau melarang untuk bekerja yang layak di dalam atau di luar rumah sehingga korban berada dibawah kendali orang tersebut.

Menurut Ashcraft dkk., kekerasan dalam rumah tangga mencakup bentuk perilaku sebagai berikut. ${ }^{7}$

a. Kekerasan fisik, seperti : menghantam, mendorong, menampar, menusuk, menendang, menggunakan senjata, melempar benda, mematahkan barang-barang, menarik rambut dan mengurung.

b. Kekerasan verbal, seperti menjatuhkan, mencaci maki, mengkritik, bersilat lidah, menghina, membuat perasaan berdosa, memperkuat perasaan takut.

c. Kekerasan ekonomi, seperti mempekerjakan dalam suatu pekerjaan, memberhentikan/membatasi pekerjaan, memanfaatkan peluang penghasilan, meminta paksa dukungan.

d. Kekerasan dengan pengasingan sosial, seperti mengawasi pergaulan dan ruang gerak, membatasi keterlibatan di masyarakat.

e. Kekerasan seksual, seperti memaksa untuk melaksanakan tindakan seksual yang tidak di kehendaki, menyeleweng, melakukan hubungan sodomi dengan kekerasan, menuduh menyeleweng, menghina cara mencapai kepuasan seks, tidak memberi kasih sayang.

f. Mengerdilkan/menyepelekan, seperti mudah melakukan kekerasan, menuduh keras yang tidak terjadi, membalas dengan kekerasan, menyalahkan melakukan kekerasan.

g. Mengintimidasi, seperti menunjukkan perangai yang menakutkan, menghancurkan barang milik, melukai binatang kesayangan, mengancam dengan senjata, mengancam untuk meninggalkan, mengambil anak-anak, mengancam bunuh diri, mengancam untuk mengungkapkan homoseksualitas ke masyarakat, para pekerja, keluarga, atau mantan pasangan.

3. Faktor Penyebab Kekerasan dalam Rumah Tangga

Kekerasan dalam rumah tangga timbul dipengaruhi oleh banyak faktor yang akar masalahnya adalah sebagai berikut. ${ }^{8}$ 
a. Masyarakat memposisikan lembaga perkawinan sebagai sesuatu yang bersifat private affair (urusan pribadi) dan oleh karenanya orang lain tidak boleh ikut campur dalam persoalan rumah tangga. Implikasi dari persepsi ini mengakibatkan lahirnya persepsi bahwa apapun yang terjadi dalam lingkup rumah tangga termasuk tindak kekerasan terhadap anggota keluarga yang lain, orang lain tidak boleh ikut campur.

b. Relasi suami istri bersifat struktural yang menempatkan suami sebagai kepala rumah tangga yang mempunyai otoritas penuh terhadap anggota keluarganya. Pada posisi ini suami mempunyai hak mengendalikan dan mengontrol secara penuh anggota keluarganya.

c. Praktek kekerasan dalam rumah tangga lahir dipengaruhi oleh dominannya budaya patriarki dan legitimasi tafsir keagamaan yang pada umumnya bias gender.

d. Secara subsantif, ketentuan-ketentuan hukum yang ada dalam ketentuan UU PKDRT banyak yang tidak jelas (clearness), disamping belum adanya kesadaran masyarakat tentang konsep kesetaraan gender, sehingga masyarakat belum mengetahui hak dan kewajibannya di hadapan hukum.

Strauss A. Murray mengidentifikasikan hal dominasi pria yang memungkinkan terjadinya kekerasan dalam rumah tangga (marital violence) sebagai berikut. ${ }^{9}$

a. Pembelaan atas kekuasaan laki-laki. yang dianggap sebagai superioritas sumber daya dibandingkan dengan wanita, sehingga mampu mengatur dan mengendalikan wanita.

b. Diskriminasi dan pembatasan di bidang ekonomi. Diskriminasi dan pembatasan kesempatan bagi wanita untuk bekerja mengakibatkan wanita (istri) ketergantungan terhadap suami, dan ketika suami kehilangan pekerjaan maka istri mengalami tindakan kekerasan.

c. Beban pengasuhan anak. Istri yang tidak bekerja, menjadikannya menanggung beban sebagai pengasuh anak. Ketika terjadi hal yang tidak diharapkan terhadap anak, maka suami akan menyalahkan istri sehingga terjadi kekerasan dalam rumah tangga.

9 M. Thoriq Nurmadiansyah, Membina Keluarga Bahagia Sebagai Upaya Penurunan Kekerasan dalam Rumah Tangga (KDRT) dalam Perspektif Agama Islam dan Undang-Undang, Musawa Vol 10 No. 2, Juli 2011, hlm. 221. 
d. Wanita sebagai anak-anak. Konsep wanita sebagai hak milik bagi laki-laki menurut hukum, mengakibatkan keleluasaan laki-laki untuk mengatur dan mengendalikan segala hak dan kewajiban wanita. Laki-laki merasa punya hak untuk melakukan kekerasan sebagai seorang bapak melakukan kekerasan terhadap anaknya agar menjadi tertib.

4 Dampak Kekerasan dalam Rumah Tangga

Perlakuan kekerasan dalam rumah tangga dapat menyebabkan tauma. Korban kekerasan dalam rumah tangga dapat mengalami trauma fisik, psikologis (mental) dan psikososial antara lain: ${ }^{10}$

a. fisik berupa luka fisik, kerusakan syaraf, pingsan, cacat permanen, gugur kandungan, kehamilan, gangguan organ reproduksi (infeksi), penyakit kelamin dan kematian.

b. psikologis/mental berupa kehilangan nafsu makan, gangguan tidur (insomnia, mimpi buruk), cemas, takut, tidak percaya diri, hilang inisiatif/tidak berdaya, tidak percaya dengan apa yang terjadi, mudah curiga/paranoid, kehilangan akal sehat, depresi berat.

Seringkali akibat dari tindakan kekerasan dalam rumah tangga tidak hanya menimpa korban secara langsung, tetapi juga anggota lain dalam rumah tangga secara tidak langsung. Tindakan kekerasan seorang suami terhadap istri atau sebaliknya, misalnya, dapat meninggalkan kesan negatif yang mendalam di hati mereka, anak-anak dan anggota keluarga yang lain. Kesan negatif ini pada akhirnya dapat pula menimbulkan kebencian dan benih-benih dendam yang tak berkesudahan terhadap pelaku. Bukan itu saja, rumah tangga yang dibangun untuk kepentingan bersama akan berantakan. Tidak jarang pelaku turut menderita karena depresi dan tekanan mental berlebihan yang dialaminya akibat penyesalanyang tiada lagi berguna. ${ }^{11}$

5. Pusat Pelayanan Terpadu Pemberdayaan Perempuan dan Anak (P2TP2A)

Untuk melaksanakan Undang-undang Nomor 23 Tahun 2004 tentang Penghapuan Kekerasan dalam Rumah Tanggal, pada tanggal 22 Oktober 2009 pemerintah membentuk Kementerian Pemberdayaan Perempuan dan Perlindungan Anak (PP dan PA). Kementerian PP dan PA mengeluarkan

10 Hawari, Penyiksaan Fisik dan Mental dalam Rumah Tangga (Domestic Violence), hlm. 104.

11 Moammad Azzam Manan, Kekerasan dalam Rumah Tangga dalam Perspektif Sosiologis, Jurnal Legislasi Indonesia, Vol 5 No. 3, September 2008, hlm. 18. 
Peraturan Menteri Negara Pemberdayaan Perempuan dan Perlindungan Anak Nomor 5 tahun 2010 tentang Panduan Pembentukan dan Pengembangan Pusat Pelayanan Terpadu. Peraturan tersebut mengatur bahwa masingmasing daerah kabupaten/kota mempunyai kewajiban membentuk Lembaga Pusat Pelayanan Terpadu Pemberdayaan dan Perlindungan Terhadap perempuan dan Anak.

Pusat Pelayanan Terpadu Pemberdayaan Perempuan dan Anak adalah lembaga layanan yang melakukan pendampingan terhadap perempuan dan anak korban kekerasan berperspektif gender. Misalnya kekerasan dalam rumah tangga meliputi kekerasan terhadap anak, kekerasan terhadap istri, pencabulan termasuk juga kasus pelecehan seksual, dan perkosaan. P2TP2A mendampingi semua perempuan dan anak korban kekerasan berperspektif gender tanpa membedakan agama, golongan, suku ataupun status sosial.

Bentuk layanan yang dilakukan ada 2 macam yaitu litigasi dan non litigasi. Layanan litigasi misalkan perkosaan, pencabulan/pelecehan seksual, dan kekerasan dalam rumah tangga. Sedangkan layanan non-litigasi misalnya konsultasi permasalahan yang tengah dihadapi, mediasi antara suami dan istri, orangtua dan anak yang sedang mempunyai masalah. Apabila korban memerlukan pendampingan hukum maka ada 2 cara yang dilakukan yaitu mendampingi secara langsung dan mendampingi secara tidak langsung. Mendampingi langsung artinya di sepanjang proses peradilan korban akan didampingi langsung oleh pendamping P2TP2A yang bertindak sebagai kuasa hukum. Sedangkan mendampingi secara tidak langsung artinya dalam bentuk konsultasi dalam menghadapi proses peradilan, membuatkan konsep gugatan dan sebagainya.

Pelayanan dilakukan pada hari kerja yaitu Senin-Jumat pukul 08.0016.00 WIB. Untuk keperluan darurat layanan konseling dapat diberikan selama 24 jam melalui nomor konselor. Adapun yang dimaksud dengan keperluan darurat apabila korban terancam keselamatannya atau membutuhkan pertolongan segera (misalnya baru saja menjadi korban perkosaan, penganiayaan) atau pada kondisi psikologis yang sangat berat seperti depresi dan akan bunuh diri. 
Segala bentuk layanan yang diberikan oleh Pusat Pelayanan terpadu Pemberdayaan Perempuan dan Anak adalah gratis atau tidak dipungut biaya apapun. Pengurus Lembaga ini terdiri dari advokat, psikolog, tokoh agama dan paralegal. Untuk memperlancar kinerja P2TP2A berjejaring dengan Rumah Sakit, Puskemas, Kepolisian, Kejaksaan dan Pengadilan.

6. Proses Pelayanan P2TP2A bagi Perempuan Korban Kekerasan dalam Rumah Tangga

Dalam hal pelayanan pengaduan, klien melapor ke P2TP2A dengan cara datang secara langsung, melalui telepon atau merupakan rujukan dari lembaga lain.

a. Pelapor melapor secara langsung

Klien diterima oleh P2TP2A, mengisi form pengaduan secara tertulis dan ditandatangani. Biasanya yang melaporkan bisa kliennya, keluarga korban, bisa pendamping yang lain. Jadi tidak harus selalu korban.

b. Penanganan pengaduan melalui telepon

Unit pelayanan penerimaan pengaduan bagi korban kekerasan harus bisa diakses melalui telepon. Nomor telepon pengaduan bisa dibuat khusus (hotline) atau disediakan dengan menggunakan nomor telepon kantor reguler. Pengaduan melalui telepon diperlukan bagi korban yang tidak mampu mengakses layanan dengan datang langsung. Pengaduan melalui telepon juga diperlukan bagi korban yang merasa belum siap bertemu langsung dengan petugas penerimaan pengaduan. ${ }^{12}$

c. Penanganan pengaduan melalui rujukan

Seringkali korban juga datang karena dirujuk oleh lembaga-lembaga lain. Dalam kasus ini, maka korban diterima sebagaimana korban yang datang secara langsung. Perbedaannya adalah sebelum mewancarai korban, petugas harus memeriksa terlebih dahulu surat rujukan maupun data-data yang dikirimkan oleh lembaga/individu perujuk. Dalam hal tidak ada surat rujukan ataupun data-data penyerta, maka langkah-langkah penanganannya sama dengan korban yang datang secara langsung. ${ }^{13}$

Alur pelayanan P2TP2A bagi klien dapat dilihat dalam bagan berikut.

KPPPA Republik Indonesia, Prosedur Standar Operasional. Ibid. 
Bagan 1.

Alur Pengaduan Langsung

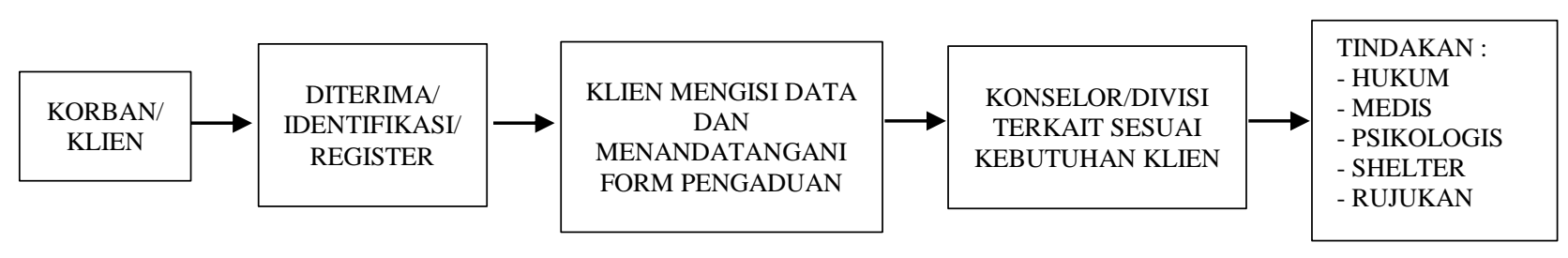

Apabila korban melakukan pengaduan langsung, korban akan diterima selanjutnya diidentifikasi kemudian diregister. Setelah itu, korban mengisi data dan menandatangani formulir pengaduan yang menunjukkan korban setuju kasusnya ditangani oleh pihak P2TP2A. Berikutnya korban diarahkan pada konselor atau divisi yang terkait sehubungan dengan pelayanan yang dibutuhkan. Misalkan pelayanan hukum, medis, psikologis, shelter (rumah aman), atau dirujuk ke lembaga lain yang berkaitan dengan masalah korban. ${ }^{14}$

\section{Bagan 2.}

\section{Pengaduan Melalui Telepon/Hotline}

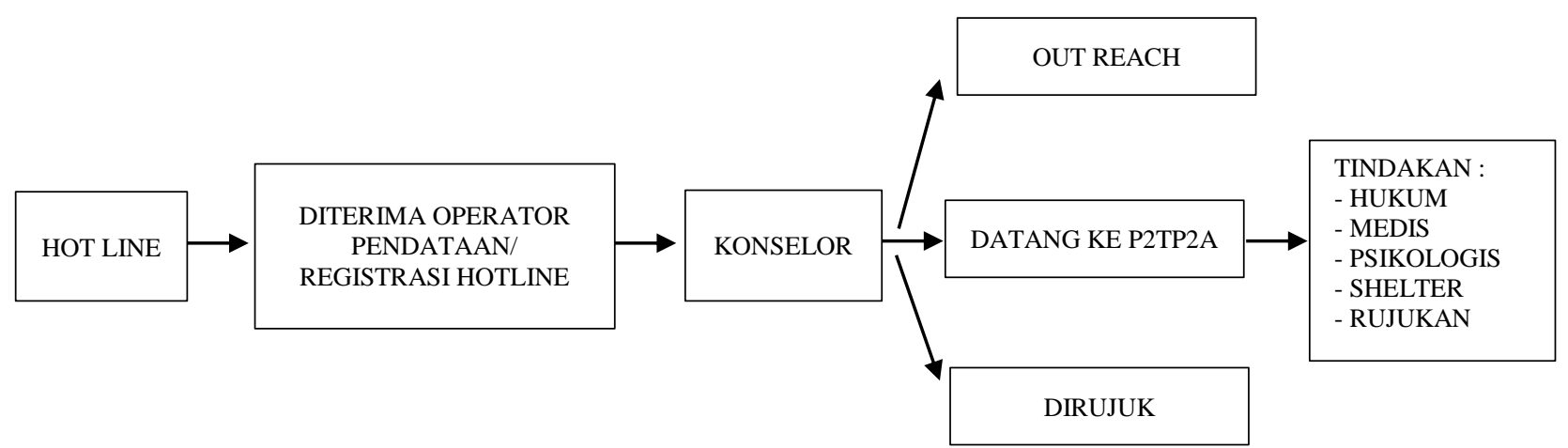

Alur pengaduan melalui hotline awalnya diterima oleh operator untuk dilakukan pendataan/dilakukan registrasi. Setelah kasusnya didentifikasi maka diserahkan ke konselor. Kemudian konselor mengambil keputusan untuk melakukan outreach (menjemput korban apabila korban tidak mampu datang sendiri), atau menyarankan korban datang langsung ke P2TP2A. Kemungkinan lainnya adalah korban dirujuk ke lembaga yang terkait. Setelah

${ }^{14}$ Wawancara dengan pengurus P2TP2A Sidoarjo As'Aluth Thoyyibah dan data yang diperoleh dari P2TP2A tanggal 21 Desember 2017. 
korban sampai P2TP2A dilakukan tindakan sesuai kebutuhan klien. Kebutuhan hukum, medis, psikologis, shelter atau rujukan ${ }^{15}$.

Bagan 3.

Alur Pengaduan Masyarakat dan Media

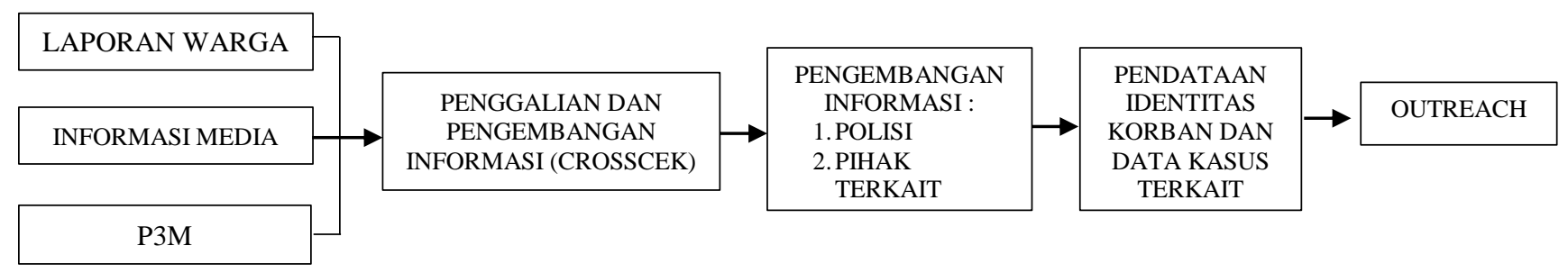

Informasi terjadinya kekerasan dalam rumah tangga juga dari laporan warga, informasi dari berbagai media (Jawa Pos, Memo, dan sebaginya) serta Pusat Pelayanan dan Pengaduan Masyarakat Kabupaten Sidoarjo. Setelah informasi diperoleh selanjutnya dilakukan pengembangan informasi kepada kepolisian maupun pihak terkait. Kemudian dilakukan pendataan identitas korban selanjutnya dilakukan outreach. ${ }^{16}$

7. Upaya P2TP2A dalam Mengatasi Masalah Kekerasan dalam Rumah Tangga

Upaya yang dilakukan P2TP2A dalam mengatasi masalah KDRT yaitu upaya pencegahan, upaya penanganan dan upaya pemulihan.

a. Upaya Pencegahan

Sebagai pencegahan dilakukan kegiatan sosialisasi dari lembaga P2TP2A yang bertujuan memberikan pelayanan bagi perempuan dan anak yang menjadi korban tindak kekerasan serta berupaya memberikan kontribusi terhadap pemberdayaan dan perlindungan perempuan dan anak dalam rangka terwujudnya kesetaraan gender. Selain memperkenalkan P2TP2A, juga sosialiasi mengenai bentuk-bentuk Kekerasan dalam rumah tangga, hukuman bagi pelaku kekerasan dalam rumah tangga dan lain sebagainya.

Selain sosialisasi pencegahan juga dilakukan penyuluhan. Penyuluhan bertujuan memberikan informasi kepada masyarakat dan meningkatkan kesadaran masyarakat mengenai Kekerasan dalam rumah 
tangga dan pencegahannya. Penyuluhan ini dilakukan berbagai instansi, di kelompok PKK, Kelompok organisasi perempuan seperti 'Aisiyah, Muslimat, dan sebagainya. ${ }^{17}$

b. Upaya Penanganan

Upaya penanganan dilakukan ketika kekerasan tersebut sudah terjadi. Upaya penanganan dilakukan dengan memberikan pelayanan medis, pelayanan psikologis, pelayanan hukum atau hanya sebatas konseling sesuai kebutuhan korban. Untuk mempermudah masyarakat menjangkau P2TP2A dibentuk pos-pos pelayanan di setiap kecamatan yang pengurusnya pengurus PKK Desa. ${ }^{18}$

c. Upaya Pemulihan

Pemulihan korban kekerasan dalam rumah tangga diarahkan pada pulihnya kondisi korban seperti semula baik fisik maupun psikis, sehingga korban dapat menjalankan aktifitasnya sehari-hari dan dapat hidup di tengah masyarakat seperti semula. Pemulihan korban dilakukan melalui pemberdayaan dan rehabilitasi sosial. Pemberdayaan dilakukan melalui pelatihan-pelatihan agar korban dapat mandiri dan tidak tergantung secara ekonomi kepada suami. Misalkan korban diberi keterampilan menjahit, memasak kemudian diberi modal usaha agar keterampilan yang diberikan tidak sia-sia. ${ }^{19}$

Zatrow mendifinisikan konsep pemberdayaan (empowerment) sebagai proses menolong individu, keluarga, kelompok dan komunitas untuk meningkatkan kekuatan personal, interpersonal, sosial ekonomi, dan politik dan pengaruhnya terhadap peningkatan kualitas hidupnya.$^{20}$

\section{KESIMPULAN}

Proses pelayanan bagi perempuan korban kekerasan dalam rumah tangga di Pusat Pelayanan Terpadu Pemberdayaan Perempuan dan Anak pertama melalui laporan. Korban bisa melapor secara langsung, hotline, media massa maupun melalui Pusat Pelayanan Pengaduan Masyarakat (P3M). Korban

\footnotetext{
17 Wawancara dengan Vira Meyrawati Raminta, Pengurus P2TP2A Sidoarjo tanggal 29 Desember 2017.

18 Ibid.

19 lbid.

20 Ariefuzzaman dan Fuaida, Op. Cit., hlm. 51.
} 
diterima, diidentifikasi dan diregister. Setelah korban mengisi data dan menandatangani formulir pengaduan selanjutnya diarahkan kepada konselor atau divisi terkait sesuai kebutuhan korban.

Pusat Pelayanan Terpadu Pemberdayaan Perempuan dan Anak dalam mengatasi kekerasan dalam rumah tangga melalui upaya pencegahan, penanganan dan pemulihan. Pencegahan dilakukan melalui sosialisasi keberadaan P2TP2A dan penyuluhan yaitu memberikan informasi serta meningkatkan kesadaran masyarakat mengenai kekerasan dalam rumah tangga. Penanganan dilakukan dengan memberikan pelayanan sesuai kebutuhan korban (pelayanan medis, hukum, psikologi, atau hanya sekedar konsultasi). Pemulihan dilakukan melalui pelatihan-pelatihan agar korban dapat mandiri serta rehabilitasi sosial agar korban dapat melaksanakan fungsinya kembali.

\section{DAFTAR PUSTAKA}

\section{Buku}

Luhulima, Archie Sudiarti, 2000, Pemahaman Bentuk-bentuk Tindak Kekerasan Terhadap Perempuan dan Alternatif Pemecahannya, PT Alumni, Bandung.

\section{Peraturan Perundang-undangan}

Undang-undang Nomor 23 Tahun 2003 tentang Penghapusan Kekerasan Dalam Rumah Tangga.

Peraturan Kementerian Pemberdayaan Perempuan dan Perlindungan Anak Nomor 5 tahun 2010 tentang Panduan Pembentukan dan Pengembangan Pusat Pelayanan Terpadu.

Keputusan Menteri Pemberdayaan Perempuan dan Perlindungan anak Tentang Prosedur Standar Operasional Pelaksanaan Pusat Pelayanan Terpadu Pemberdayaan Perempuan dan Anak.

\section{Sumber Lain}

Manan, Moch. Azzam, Kekerasan dalam Rumah Tangga dalam Perspektif Sosiologis, Jurnal Legislasi Indonesia, Vol. 5 No. 3, September 2008.

Normadiansyah, M. Thoriq, Membina Keluarga Bahagia Sebagai Upaya Penurunan Kekerasan Dalam Rumah Tangga (KDRT) dalam Perspektif Agama Islam dan Undang-undang, Musawa, Vol. 10 No. 2, Juli 2011. 